\title{
ANALISIS KINERJA KEUANGAN TERHADAP HARGA SAHAM \\ (Pada Perusahaan Perbankan Yang Terdaftar Di Bursa Efek Indonesia
}

Periode 2015-2019)

\author{
Camelia Hariyani ${ }^{1}$
}

Burhanudin ${ }^{2}$

Ratna Damayanti ${ }^{3}$

cameliahariyani2@gmail.com ${ }^{1}$

\section{Universitas Islam Batik Surakarta}

Diterima : November 2020, Disetujui : Desember 2020, Dipublikasikan: Januari 2021

\begin{abstract}
This study aims examine the effect of Return On Assets, Non Performing Loan, and Price Earning Ratio on bank stock price listed on the Indonesia Stock Exchange. The population in this study were 42 banking companies listed on the Indonesia Stock Exchange in 2015-2019. The sampling technique used in this study was purposive sampling which resulted in a sample of 10 banking companies. The data used in this study are secondary data in the form of financial report and stock price taken through the official website of each sample bank and also from Indonesia Capital Market Directory (ICMD). The result of this study indicated that Return On Assets has no significant positive effect on bank stock price, Non Performing Loan have a significant negative effect on bank stock price, and Price Earning Ratio has a significant positive effect on bank stock price.
\end{abstract}

Keywords : ROA, NPL, PER, Stock Price

\section{ABSTRAK}

Penelitian ini bertujuan untuk menguji pengaruh Return On Assets, Non Performing Loan, dan Price Earning Ratio terhadap harga saham perbankan yang terdaftar di Bursa Efek Indonesia. Populasi dalam penelitian ini adalah 42 perusahaan perbankan yang terdaftar di Bursa Efek Indonesia Tahun 2015-2019. Teknik pengambilan sampel pada penelitian ini menggunakan purposive sampling yang menghasilkan sampel sejumlah 10 perusahaan perbankan. Data yang digunakan dalam penelitian ini adalah data sekunder berupa laporan keuangan dan harga saham yang diambil melalui website resmi dari masing-masing bank yang dijadikan sampel dan juga dari Indonesia Capital Market Directory (ICMD). Hasil 
penelitian ini menunjukkan bahwa Return On Assets tidak berpengaruh positif signifikan terhadap harga saham perbankan, Non Performing Loan berpengaruh negatif signifikan terhadap harga saham perbankan dan Price Earning Ratio berpengaruh positif signifikan terhadap harga saham perbankan.

Kata Kunci : ROA, NPL, PER, Harga Saham

\section{PENDAHULUAN}

Tahun 2015 menjadi tahun yang cukup berat bagi perekonomian Indonesia, dimana pada tahun tersebut Indonesia dihadapkan dengan berbagai tantangan baik secara global maupun domestik. Dengan adanya permasalahan global tersebut mengakibatkan dampak negatif bagi perekonomian domestik di Indonesia, baik melalui jalur perdangangan maupun keuangan. Apabila kondisi tersebut tidak dikelola dengan baik maka dapat mengakibatkan melemahnya pertumbuhan ekonomi di Indonesia. Dengan kondisi perekonomian yang sedang dihadapkan dengan berbagai tantangan, perbankan yang memiliki peranan sebagai sumber pembiayaan dalam negeri diharapkan mampu mendongkrak roda perekonomian negara. Perkembangan industri perbankan membutuhkan modal yang cukup besar dalam mendukung ekspansinya maupun untuk memenuhi ketentuan dari OJK sebagai regulatornya. Dalam memenuhi kebutuhan modal, suatu perbankan dapat melakukan secara internal maupun eksternal. Apabila pemenuhan modal secara internal tidak dapat mencukupi kebutuhan modal, maka pemenuhan secara ekternal dapat dilakukan dengan cara melakukan IPO atau menjual sahamnya di pasar modal.

Pada pasar modal terbentuk suatu harga saham melalui hukum ekonomi atas permintaan dan penawaran yang terjadi. Meningkatnya harga saham pada suatu perusahaan dapat terjadi dikarenakan adanya kenaikan permintaan saham tersebut. Apabila tingkat suatu harga saham rendah dan peminantnya sedikit dapat menyebabkan meningkatnya resiko ketidaklancaran arus permodalan perusahaan karena kurangnya modal untuk menjalankan kegiatan perusahaan tersebut (Fahlevi et al, 2018). Dalam membeli saham atau memilih suatu investasi, seorang investor harus melakukan penilaian terlebih dahulu terhadap perusahaan yang akan dituju. Salah satu cara penilaian yang dapat dilakukan dengan melihat kinerja perusahaan melalui laporan keuangan perusahaan yang di ukur menggunakan rasio keuangan.

Rasio keuangan yang digunakan oleh Yuliyanti, et al. (2017) dalam penelitiannya adalah rasio permodalan menggunakan CAR, likuiditas menggunakan LDR dan rentabilitas menggunakan ROA. Penelitian yang dilakukan Mutiarani, et al. (2019) menggunakan rasio pasar berupa PER dan PBV dalam mengukur pengaruh kinerja keuangan terhadap harga saham. Sedangkan penelitian Sambul, et al. (2016) menggunakan rasio CAR, ROA, NPL dan LDR sebagai rasio yang digunakan untuk mengukur pengaruh kinerja keuangan terhadap harga saham. Pada penelitian ini menggunakan rasio rentabilitas yang diukur menggunakan ROA, rasio kredit menggunakan NPL dan rasio pasar menggunakan PER untuk mengetahui pengaruhnya terhadap harga saham perbankan. 
Return On Assets (ROA)mencerminkan asset yang dimiliki suatu perbankan dalam menghasilkan laba. Batas minimum ROA menurut ketentuan Bank Indonesia adalah sebesar 1,5\%. Hasil Penelitian yang dilakukan Yuliyanti, et al. (2019) dan Fahlevi, et al. (2018) menunjukkan bahwa variabel ROA berpengaruh terhadap harga saham. Sedangkan penelitian yang dilakukan oleh Murwanti dan Mulyono (2015) menunjukkan hasil yang berbeda bahwa ROA tidak berpengaruh terhadap harga saham.

Non Performing Loan (NPL) merupakan rasio yang mencerminkan tingkat kesehatan bank dan kinerja bank dalam pemberian kredit. Menurut Surat Edaran Bank Indonesia, bank dinyatakan dalam kondisi sehat apabila nilai NPL nya < 5\%. Hasil penelitian Nureny (2019) dan Sambul, et al. (2016) menunjukkan hasil bahwa variabel NPL tidak berpengaruh terhadap harga saham sedangkan penelitian Marwansyah (2016) menunjukkan bahwa NPL berpengaruh terhadap harga saham.

Price Earning Ratio (PER) merupakan rasio perbandingan antara harga saham dengan laba yang diterima. Nilai PER juga dapat menunjukkan nilai dari laba yang dihasilkan oleh suatu perusahaan, apabila nilai PER menunjukkan hasil yang positif maka dapat dikatakan bahwa pertumbuhan laba mempunyai pengaruh poisitif terhadap harga saham. Berdassarkan penelitian oleh Sapariyah, et al. (2016) dan Husna (2016) menunjukkan bahwa variabel PER berpengaruh terhadap harga saham sedangkan penelitian yang dilakukan oleh Mutiarani, et al. (2019) menunjukkan hasil yang berbeda bahwa variabel PER tidak berpengaruh terhadap harga saham.

Berdasarkan pemaparan uraian diatas dan juga dengan adanya research gap ini menjadikan celah bagi penulis untuk membuat penelitian dengan judul "Analisis Kinerja Keuangan Terhadap Harga Saham Pada Perbankan Yang Terdaftar di Bursa Efek Indonesia Periode 2015-2019". Adapun tujuan dari penelitian ini untuk mengetahui pengaruh antara Return On Assets, Non Performing Loan dan Price Earning Ratio terhadap harga saham perbankan yang terdaftar di BEI 2015-2019.

\section{LANDASAN TEORI}

\section{Singlaning Theory}

Signaling theory merupakan suatu cara pandang investor mengenai prospek perusahaan dalam meningkatkan nilainya di masa mendatang (Brigham dan Houtson, 2014). Sinyal yang dimaksudkan biasanya berupa sebuah informasi mengenai sesuatu yang telah dilakukan oleh pihak manajemen dalam mewujudkan keinginan dari pemilik. Ketika semua pihak telah menerima informasi tersebut, maka pihak-pihak yang menerima informasi dapat menganalisis apakah informasi tersebut termasuk sinyal baik (good news) atau bahkan sinyal buruk (bad news).

\section{Harga Saham}

Harga saham dapat dikatakan sebagai suatu nilai yang dibayar oleh seorang investor untuk mendapatkan hak kepemilikan atas suatu perusahaan. Harga saham adalah suatu harga 
yang terjadi di pasar modal pada waktu tertentu yang ditentukan oleh para pelaku pasar (Jogiyanto, 2014). Harga saham dalam pasar modal selalu mengalami fluktuasi dikarenakan oleh tinggi rendahnya permintaan akan saham tersebut.

\section{Kinerja Keuangan}

Kinerja Keuangan merupakan suatu informasi yang digunakan sebagai acuan atau tolak ukur bagi seorang investor untuk mengambil keputusan apakah mempertahankan investasinya ataupun mencari alternatif lain (Marwansyah, 2016).

\section{Return On Assets}

Rentabilitas merupakan suatu rasio yang bertujuan untuk mengukur tingkat efektifitas perusahaan dalam menjalankan kegaiatan operasionalnya. Dalam penelitian ini, rasio rentabilitas di proksikan dengan rasio Return On Assets. Return On Assets adalah rasio yang berfungsi untuk mengukur tingkat efektifitas suatu perusahaan dalam memperoleh keuntungan dengan cara memanfaatkan aktiva yang dimilikinya (Husna, 2016).

\section{Non Performing Loan}

Non Performing Loan merupakan rasio yang menggambarkan tingkat kesehatan suatu bank dan juga mencerminkan kemampuan perbankan dalam mengelola kerdit bermasalah. Non Performing Loan dapat diartikan sebagai suatu pinjaman (utang) yang sulit dalam proses pelunasannya, yang biasa disebut dengan kredit macet (Yuliyanti et al, 2017)

\section{Price Earning Ratio}

Price Earning Ratio merupakan rasio yang digunakan untuk mengukur seberapa besar jumlah yang dibayarkan oleh seorang investor umtuk setiap nilai laba berdasarkan pada periode tertentu (Sapariyah et al, 2016).

\section{Kerangka Pemikiran}

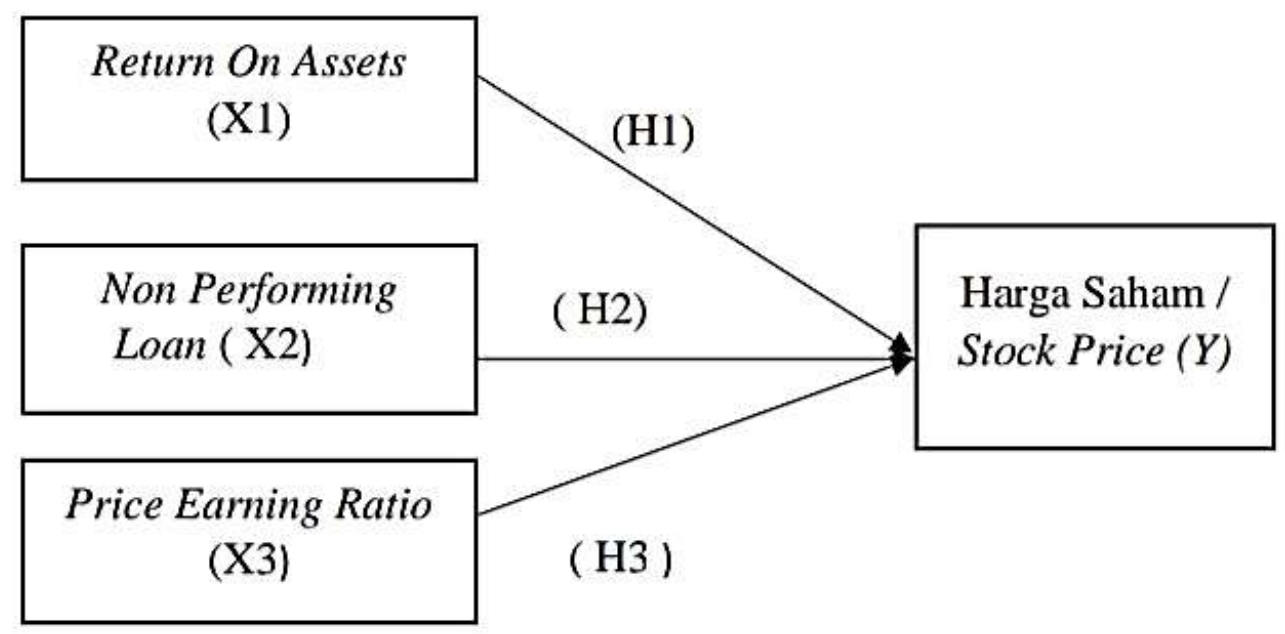

Gambar 1 


\section{Kerangka Pemikiran}

Berdasarkan kerangka pemikiran diatas maka hipotesis pada penelitian ini adalah sebagai berikut :

H1 : Terdapat Pengaruh antara Return On Assets terhadap harga saham

H2 : Terdapat Pengaruh antara Non Performing Loan terhadap harga saham

H3 : Terdapat Pengaruh antara Price Earning Ratio terhadap harga saham

\section{METODE PENELITIAN}

\section{Ruang Lingkup Penelitian}

Jenis penelitian ini merupakan penelitian kausal dengan metode kuantitatif yang memiliki tujuan untuk mengetahui pengaruh kinerja keuangan terhadap harga saham perbankan yang terdaftar di Bursa Efek Indonesia Periode 2015-2019.

\section{Jenis dan Sumber Data}

Jenis data yang digunakan adalah jenis data kuantitaif dengan sumber data sekunder yang diambil melaui website resmi dari masing-masing bank yang dijadikan sampel untuk data keuangan dan untuk harga saham diambil melalui Indonesia Capital Market Directory (ICMD).

\section{Populasi dan Sampel Penelitian}

Populasi dalam penelitian ini adalah 42 perusahaan perbankan yang terdaftar di BEI periode 2015-2019. Jumlah sampel pada penelitian ini yaitu 10 perusahaan perbankan. Sampel diperoleh menggunakan teknik purposive sampling.

\section{Metode Pengumpulan Data dan Analisis Data}

Pengumpulan data menggunakan teknik pengumpulan data secara time series selama 5 tahun yang diambil melalui laporan keuangan dan harga saham perbankan. Analisis data menggunakan teknik analisis regresi linier berganda dengan bantuan SPSS 15 .

\section{Definisi Operasional Variabel}

Dalam penelitian ini menggunakan variabel dependen yaitu harga saham dan variabel 129ndependent Return On Assets, Non Performing Loan dan Price Earning Ratio. Berikut penjelasan mengenai masing-masing variabel tersebut : 
Harga Saham

Harga saham yang digunakan dalam penelitian ini adalah harga pada saat penutupan atau closing price yaitu pada pukul 14.59.

Return On Assets

Rentabilitas yang digunakan pada penelitian ini adalah rasio Return On Assets. Adapun rumus yang digunakan untuk menghitung ROA adalah sebagai berikut :

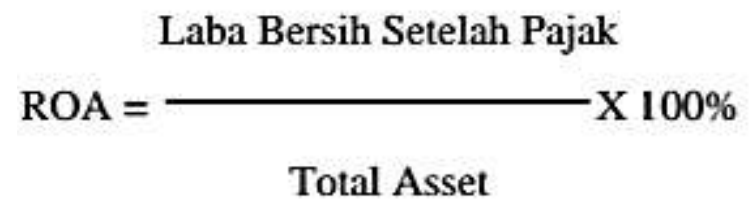

Non Performing Loan

Rasio pemberian kredit dalam penelitian ini menggunakan rasio Non Performing Loan. Adapun rumus menghitung NPL adalah sebagai berikut :

\section{Kualitas Produktif Bermasalah}

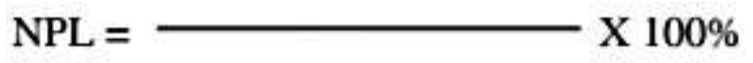

\section{Aktiva Produktif}

Price Earning Ratio

Rasio pasar yang digunakan untuk mengetahui perbandingan harga saham dengan laba menggunakan rasio Price Earning Ratio. Berikut rumus untuk menghitung PER :

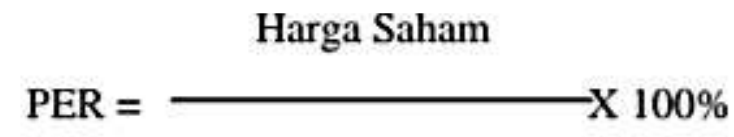

\section{Earning Per Lembar Saham}




\section{HASIL DAN PEMBAHASAN}

\section{Hasil}

\section{Uji Asumsi Klasik}

Adapun uji asumsi klasik yang dilakukan dalam penelitian ini adalah sebagai berikut :

1. Uji Normalitas

\section{Tabel 1}

\section{Hasil Uji Normalitas Kolmogorov Smirnov}

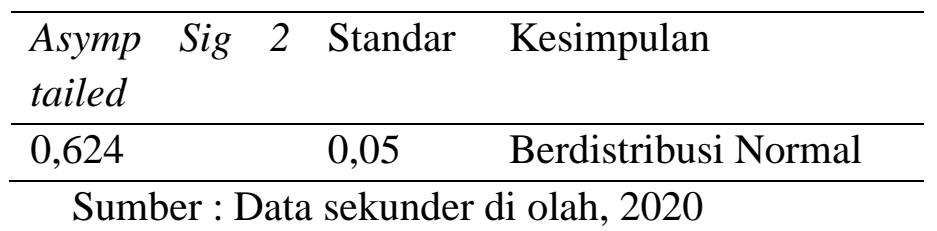

Berdasarkan hasil pengujian normalitas menggunakan Kolmogorov Smirnov pada tabel 1 menunjukkan bahwa nilai Asymp Sig 2 tailed sebesar 0,624 yang berarti lebih besar dari standar 0,05 maka dapat disimpulkan bahwa data pada penelitian ini berdistribusi normal. Dengan hasil tersebut mengindikasikan bahwa persayarat uji asumsi klasik normalitas pada model regresi terpenuhi.

2. Uji Multikolinieritas

\section{Tabel 2}

\section{Hasil Uji Multikolinieritas}

\begin{tabular}{|c|c|c|c|c|c|}
\hline Variabel & Tolerance & $\begin{array}{l}\text { Std } \\
\text { Tolerance }\end{array}$ & VIF & Std VIF & Kesimpulan \\
\hline $\begin{array}{l}\mathrm{ROA} \\
\left(\mathrm{X}_{1}\right)\end{array}$ & 0,925 & $>0,1$ & 1,082 & $<10$ & $\begin{array}{l}\text { Tidak terjadi } \\
\text { multikolinieritas }\end{array}$ \\
\hline $\begin{array}{l}\mathrm{NPL} \\
\left(\mathrm{X}_{2}\right)\end{array}$ & 0,924 & $>0,1$ & 1,082 & $<10$ & $\begin{array}{l}\text { Tidak terjadi } \\
\text { multikolinieritas }\end{array}$ \\
\hline $\begin{array}{l}\text { PER } \\
\left(\mathrm{X}_{3}\right)\end{array}$ & 0,995 & $>0,1$ & 1,005 & $<10$ & $\begin{array}{l}\text { Tidak terjadi } \\
\text { multikolinieritas }\end{array}$ \\
\hline
\end{tabular}

Sumber : Data sekunder di olah, 2020

Berdasarkan hasil pengujian tabel 2 diatas dapat diketahui bahwa nilai tolerance dari variabel independen lebih besar dari 0,1 dan nilai VIF kurang dari 10, maka dapat disimpulkan bahwa pada penelitian ini tidak terjadi multikolinieritas. 
3. Uji Heterokedastisitas

\section{Tabel 3}

Hasil Uji Heterokedastisitas Rank Spearman

\begin{tabular}{|c|c|c|c|c|}
\hline Variabel & $\begin{array}{l}\text { Sig } \\
\text { tailed }\end{array}$ & 2 Standar & Kesimpulan & \\
\hline $\begin{array}{l}\mathrm{ROA} \\
\left(\mathrm{X}_{1}\right)\end{array}$ & 0,501 & $>0,05$ & $\begin{array}{l}\text { Tidak } \\
\text { heterokedastisitas }\end{array}$ & terjadi \\
\hline $\operatorname{NPL}\left(\mathrm{X}_{2}\right)$ & 0,147 & $>0,05$ & $\begin{array}{l}\text { Tidak } \\
\text { heterokedastisitas }\end{array}$ & terjadi \\
\hline $\operatorname{PER}\left(\mathrm{X}_{3}\right)$ & 0,755 & $>0,05$ & $\begin{array}{l}\text { Tidak } \\
\text { heterokedastisitas }\end{array}$ & terjadi \\
\hline
\end{tabular}

Sumber : Data sekunder di olah, 2020

Berdasarkan hasil uji heterokedastisitas menggunakan rank spearman pada tabel 3 menunjukkan hasil sig 2 tailed dari semua variabel independen lebih besar dari 0,05 yang berarti bahwa tidak terjadi heterokedastisitas pada model regresi.

4. Uji Autokorelasi

Tabel 4

Hasil Uji Autokorelasi Run Test

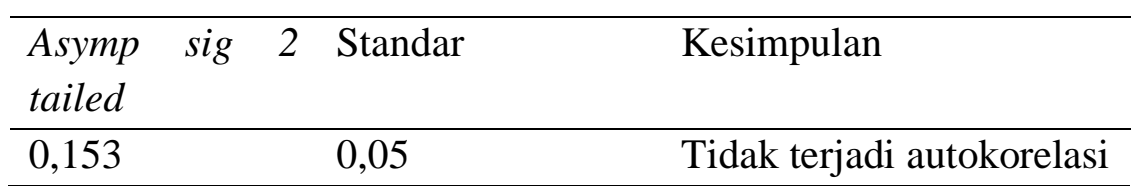

Sumber : Data sekunder di olah, 2020

Berdasarkan hasil pengujian autokorelasi menggunakan run test pada tabel 4 menunjukkan bahwa nilai Asymp sig 2 tailed sebesar 0,153 yang berarti > 0,05. Maka dapat diperoleh kesimpulan bahwa pada penelitian ini tidak terjadi autokorelasi pada model regresi.

\section{Analisis Regresi Linier Berganda}

Tabel 5

\section{Hasil Regresi Linier Berganda}

\begin{tabular}{ll}
\hline Model & $\mathrm{B}$ \\
\hline Constant & 4354,975 \\
\hline Return On Assets $\left(\mathrm{X}_{1}\right)$ & 340,868 \\
\hline Non Performing Loan & $-3606,298$ \\
$\left(\mathrm{X}_{2}\right)$ & \\
\hline Price Earning Ratio & 679,296 \\
$\left(\mathrm{X}_{3}\right)$ & \\
\hline
\end{tabular}

Sumber : Data sekunder di olah, 2020 
Berdasarkan hasil pengujian regresi linier berganda diatas, maka diperoleh persamaan regresi sebagai berikut :

$$
\begin{aligned}
& Y=\alpha+\beta_{1} X_{1}+\beta_{2} X_{2}+\beta_{3} X_{3}+e \\
& Y=4354,975+340,868 X_{1}-3606,298 X_{2}+679,296 X_{3}+e
\end{aligned}
$$

Adapun penjelasanya adalah sebagai berikut :

1) Konstanta sebesar 4354,975 menunjukkan bahwa jika variabel independen ROA $\left(\mathrm{X}_{1}\right)$, NPL $\left(\mathrm{X}_{2}\right)$, PER $\left(\mathrm{X}_{3}\right)$ nilainya 0 maka nilai dari variabel dependen harga saham adalah sebesar Rp 4354,975.

2) Koefisien regresi variabel independen ROA $\left(\mathrm{X}_{1}\right)$ sebesar 340,868 menunjukkan bahwa jika ROA mengalami kenaikan $1 \%$ dan variabel independen lain nilainya tetap (konstan) maka harga saham akan mengalami kenaikan sebesar Rp 340,868.

3) Koefisien regresi variabel independen NPL $\left(\mathrm{X}_{2}\right)$ sebesar - 3606,298 menunjukkan bahwa jika NPL mengalami kenaikan $1 \%$ dan variabel independen lain nilainya tetap (konstan) maka harga saham akan mengalami penurunan sebesar Rp 3606,298 .

4) Koefisien regresi variabel independen PER $\left(\mathrm{X}_{3}\right)$ sebesar 679,296 menunjukkan bahwa jika PER mengalami kenaikan $1 \%$ dan variabel independen lain nilainya tetap (konstan) maka harga saham akan mengalami kenaikan sebesar Rp 679,296.

\section{Uji Hipotesis}

Adapun uji asumsi klasik yang dilakukan dalam penelitian ini adalah sebagai berikut :

1. Uji t

\section{Tabel 6}

\section{Hasil Hipotesi Uji t}

\begin{tabular}{lllllll}
\hline Variabel & $\mathrm{t}$ hitung & $\mathrm{t}$ tabel & $\mathrm{Sig}$ & Standar & Kesimpulan & \\
\hline ROA & 1,708 & 2,012 & 0,094 & $<0,05$ & $\begin{array}{l}\text { H0 diterima } \\
\text { ditolak }\end{array}$ & H1 \\
\hline NPL & $-4,545$ & $-2,012$ & 0,000 & $<0,05$ & $\begin{array}{l}\text { H0 ditolak } \\
\text { diterima }\end{array}$ & H2 \\
\hline PER & 6,341 & 2,012 & 0,000 & $<0,05$ & $\begin{array}{l}\text { H0 ditolak } \\
\text { diterima }\end{array}$ & H3 \\
\hline
\end{tabular}

Sumber : Data sekunder di olah, 2020

Dasar pengambilan keputusan pada uji hipotesis menggunakan uji t adalah jika nilai $\mathrm{t}$ hitung $>\mathrm{t}$ tabel dan tingkat signifikan $<0,05$ maka diperoleh kesimpulan bahwa H0 ditolak dan $\mathrm{H} 1$ diterima. Berdasarkan tabel 6 diatas menunjukkan jika variabel ROA tidak berpengaruh terhadap harga saham sedangkan variabel NPL dan PER berpengaruh terhadap harga saham. 
2. Uji Determinasi $\mathrm{R}^{2}$

\section{Tabel 7}

\section{Hasil Uji Determinasi $\mathbf{R}^{2}$}

\begin{tabular}{ll}
\hline Adjusted $R$ Square & Kesimpulan \\
\hline 0,610 & Berpengaruh sebesar 61\% \\
\hline
\end{tabular}

Sumber : Data sekunder di olah, 2020

Berdasarkan hasil pada tabel 7 menunjukkan bahwa nilai Adjusted $R$ Square sebesar 0,610 yang berarti bahwa variabel independen yang terdiri dari ROA, NPL dan PER mempunyai pengaruh terhadap harga saham sebesar $61 \%$.

\section{Pembahasan}

1. Pengaruh Return On Assets Terhadap Harga Saham

Berdasarkan hasil penelitian diatas menunjukkan bahwa Return On Assets tidak berpengaruh positif signifikan terhadap harga saham. Artinya bahwa apabila nilai Return On Assets mengalami kenaikan maka tidak akan mempengaruhi harga saham. Hal ini dikarenakan Return On Assets memiliki kelemahan yakni dapat membuat pihak manajemen hanya berfokus pada tujuan jangka pendek untuk mendapatkan nilai Return On Assets yang tinggi (Susanto, 2005). Sehingga menyebabkan investor yang memiliki tujuan jangka panjang tidak memperhatikan nilai ROA dalam melakukan investasi.

Hasil penelitian ini sejalan dengan penelitian yang dilakukan oleh Murwanti dan Mulyono (2015) yang menyatakan bahwa variabel Return On Assets tidak memiliki pengaruh terhadap harga saham perbankan. Namun, hasil penelitian ini bertolak belakang dengan hasil penelitian yang dilakukan oleh Yuliyanti, et al. (2017) dan Fahlevi, et al. (2018) yang menyatakan bahwa variabel Return On Assets secara parsial berpengaruh terhadap harga saham perbankan.

2. Pengaruh Non Performing Loan Terhadap Harga Saham

Berdasarkan hasil penelitian diatas menunjukkan bahwa Non Performing Loan berpengaruh negatif signifikan terhadap harga saham. Artinya bahwa nilai Non Performing Loan mengalami kenaikan maka harga saham akan mengalami penurunan begitu juga sebaliknya. Nilai Non Performing Loan rendah maka dapat mencerminkan tingkat kesehatan bank, dimana menurut Surat Edaran Bank Indonesia nilai NPL < 5\% maka mengindikasikan bahwa bank tersebut dinyatakan sehat. Sehingga tingkat Non Performing Loan yang rendah mempunyai daya tarik bagi investor dalam membeli saham perbankan yang mengakibatkan kenaikan dari harga saham tersebut.

Hasil penelitian ini didukung oleh penelitian Marwansyah (2016) yang menyatakan bahwa variabel Non Performing Loan memiliki pengaruh terhadap harga saham bank BUMN pada Bursa Efek Indonesia. Namun penelitian ini bertolak belakang dengan penelitian yang dilakukan oleh Sambul, et al. (2016) dan Nureny 
(2019) yang menyatakan bahwa variabel Non Performing Loan tidak berpengaruh terhadap harga saham perbankan.

3. Pengaruh Price Earning Ratio Terhadap Harga Saham

Hasil penelitian menunjukkan bahwa Price Earning Ratio berpengaruh positif signifikan terhadap harga saham, Hal ini berarti apabila nilai Price Earning Ratio mengalami kenaikan maka harga saham juga akan mengalami kenaikan. Hal ini disebabkan Price Earning Ratio dapat mengindikasikan kepercayaan seorang investor akan prospek perusahaan kedepannya, sehingga menyebabkan investor tertarik membeli saham perusahaan tersebut yang mengakibatkan kenaikan pada harga saham.

Hasil penelitian ini sejalan dengan penelitian yang dilakukan oleh Sapariyah, et al. (2016) dan Husna (2016) yang menyatakan bahwa variabel Price Earning Ratio memiliki pengaruh secara parsial terhadap perusahaan perbankan yang terdaftar di BEI. Namun penelitian ini tidak sejalan dengan penelitian yang dilakukan oleh Mutiarani, et al. (2019) yang menunjukkan hasil bahwa variabel Price Earning Ratio secara parsial tidak memiliki pengaruh terhadap harga saham perusahaan yang terdaftar di BEI.

\section{KESIMPULAN DAN SARAN}

\section{Kesimpulan}

1. Return On Asset tidak berpengaruh positif signifikan terhadap harga saham perbankan yang terdaftar di BEI periode 2015-2019.

2. Non Performing Loan berpengaruh negatif signifikan terhadap harga saham perbankan yang terdaftar di BEI periode 2015-2019.

3. Price Earning Ratio berpengaruh positif signifikan terhadap harga saham perbankan yang terdaftar di BEI periode 2015-2019.

\section{Saran}

1. Bagi perusahaan hendaknya meningkatkan kinerja perusahaan agar mampu bersaing dalam memikat investor. Sehingga dapat memenuhi kebutuhan modal dari luar yang akan membantu dalam berkembangnya perusahaan.

2. Bagi Investor khususnya yang akan berinvestasi pada sektor perbankan hendaknya dapat memperhatikan nilai NPL dan PER perusahaan sebelum melakukan investasi.

3. Bagi peneliti selanjutnya diharapkan menggunakan objek yang lebih luas dan juga dapat menambah variabel dalam penelitiannya.

\section{DAFTAR PUSTAKA}

Bank, D. (2019). Laporan Tahunan. http://www.danamon.co.id

BCA. (2019). Laporan Tahunan. https://www.bca.co.id

BNI. (2019). Laporan Tahunan. http://www.bni.co.id

BRI. (2019). Laporan Tahunan. http://www.bri.co.id 
Brigham, \& Houston. (2014). Essentials of Financial Management. Salemba Empat.

BTN. (2019). Laporan Tahunan. http://www.btn.co.id

CIMB Niaga. (2019). Laporan Tahunan. http://www.cimbniaga.co.id

Fahlevi, R. R., Asmapane, S., \& Oktavianti, B. (2018). Pengaruh Kinerja Keuangan Terhadap Harga Saham Pada Perusahaan Perbankan Yang Terdaftar di Bursa Efek Indonesia. Akuntabel.

Husna, N. (2016). Analisis Pengaruh Kinerja Keuangan Terhadap Harga Saham Pada Perusahaan Perbankan. E-Jurnal Apresiasi Ekonomi, 4.

IDX. (2020). Ringkasan Performa Perusahaan Tercatat. http://www.idx.co.id

Indonesia, B. (2015). Bersinergi Melawal Stabilitas, Mewujudkan Reformasi Struktural.

Jogiyanto. (2014). Teori Portofolio dan Analisis Investasi (10th ed.). BPFE.

Mandiri, B. (2019). Laporan Tahunan. http://www.bankmandiri.co.id

Marwansyah, S. (2016). Analisis Kinerja Keuangan Terhadap Harga Saham Pada Bank BUMN. Moneter, III.

Maybank. (2019). Laporan Keuangan Tahunan. http://www.maybank.co.id

Murwanti, \& Mulyono. (2015). Analisis Pengaruh Rasio Keuangan Terhadap Harga Saham Perusahaan Perbankan Yang Terdaftar Di Bursa Efek Indonesia (BEI Th 2010-2012). Benefit Jurnal Managemen Dan Bisnis, 19, 136-142.

Mutiarani, Niki, N., Dewi, R., \& Suhendro. (2019). Pengaruh Price Earning Ratio, Price To Book Value Dan Inflasi Terhadap Harga Saham Yang Terindeks IDX 30. Edunomika, 03.

Nureny. (2019). Financial Performance and Share Prices of Banks of State Owned Enterprise In Indonesia. Jurnal Ilmiah Ilmu Administrasi Publik, 9.

OCBC NISP. (2019). Laporan Tahunan. http://www.ocbcnisp.co.id

Panin, B. (2019). Laporan Tahunan. http://www.panin.co.id

Sambul, Sandro, H., Murni, S., \& Tumiwa, J. R. (2016). Pengaruh Kinerja Keuangan Perbankan Terhadap Harga Saham Yang Di Tawarkan Di Bursa Efek Indonesia (Studi Kasus 10 Bank Dengan Asset Terbesar). Jurnal Berkala Ilmiah Efisiensi, 16.

Sapariyah, Rina, A., Khristiana, Y., \& Juwanto. (2016). Return On Assets, Debt Equity Ratio, Price Earning Ratio, Kurs dan Inflasi Terhadap Harga Saham. Advande, 4.

Susanto, B. (2005). Manajemen Akuntansi. Sansu Moto

Yuliyanti, L., Muntasofi, B., \& Asih, Nuraeni, D. (2017). Pengaruh Kinerja Keuangan Terhadap Harga Saham Bank Umum Konvensional di Bursa Efek Indonesia Pada Tahun 2013-2016. Jurnal Pendidikan Akuntansi Dan Keuangan, 5. 